\title{
Organization of project activities in the system of advanced training of teachers
}

\section{Organización de actividades de proyectos en el sistema de desarrollo profesional del profesorado}

\author{
Inna K. Kirillova \\ Moscow State University of Civil Engineering, Moscow, Russia \\ ORCID: https://orcid.org/0000-0002-9873-4832 \\ Irina V. Akimova $\mathbb{C}$ \\ Penza State University, Penza, Russia. \\ ORCID: https://orcid.org/0000-0003-0900-4676 \\ Oksana P. Denisova \\ Togliatti State University, Togliatti, Russia \\ ORCID: https://orcid.org/0000-0001-8544-6957 \\ Olga I. Vaganova \\ Minin Nizhny Novgorod State Pedagogical University, Russia. \\ ORCID: https://orcid.org/0000-0001-8347-484X \\ Natalia E. Zhitnikova \\ Minin Nizhny Novgorod State Pedagogical University, Russia. \\ ORCID: https://orcid.org/0000-0001-8547-3699
}

*Correspondence

Email: ivannovadremova29@gmail.com
Cite as:

Kirillova, I., Akimova, I., Denisova, O., Vaganova, O., Zhitnikova, N. (2021). Organization of project activities in the system of advanced training of teachers. Propósitos $y$ Representaciones, 9 (SPE1), e809. Doi: http://dx.doi.org/10.20511/pyr2021.v9nSPE1.e809 


\section{Summary}

Project activity occupies an important place in the system of professional development. Focused on a rapidly changing environment, it provides the widest opportunities for innovative development of the field of additional education. The implementation of project activities allows you to form important for students of courses, leading decisions in the context of global educational competition and high uncertainty of the educational environment. The purpose of the article is to study the experience of organizing project activities in the system of professional development of teachers. Project activity is a joint educational creative activity of course participants that has a common goal and agreed methods to achieve it. The article reveals the experience of project activities of students in the framework of the course "Management in education". In the process of implementing project activities, the project competence of students is formed. Project activity occupies an important place in the system of professional development. Its implementation allows you to radically change the entire learning process, make it active, creative and independent.

Key Words: advanced training, project activities, course, project competence, vocational training.

\section{Resumen}

La actividad del proyecto ocupa un lugar importante en el sistema de desarrollo profesional. Centrado en un entorno que cambia rápidamente, ofrece las más amplias oportunidades para el desarrollo innovador del campo de la educación adicional. La implementación de las actividades del proyecto le permite formar importantes para los estudiantes de los cursos, liderando decisiones en el contexto de competencia educativa global y alta incertidumbre del entorno educativo. El propósito del artículo es estudiar la experiencia de organizar actividades de proyectos en el sistema de desarrollo profesional de los docentes. La actividad del proyecto es una actividad creativa educativa conjunta de los participantes del curso que tiene un objetivo común y métodos acordados para lograrlo. El artículo revela la experiencia de las actividades de proyectos de los estudiantes en el marco del curso "Gestión en la educación". En el proceso de implementación de las actividades del proyecto, se forma la competencia del proyecto de los estudiantes. La actividad del proyecto ocupa un lugar importante en el sistema de desarrollo profesional. Su implementación te permite cambiar radicalmente todo el proceso de aprendizaje, hacerlo activo, creativo e independiente

Palabras clave: formación avanzada, actividades del proyecto, curso, competencia del proyecto, formación profesional.

\section{Introducción}

With the development of the trend of lifelong learning (continuing education), there is a need to improve the training of students in the framework of additional professional education (Pichugina \& Bondarchuk, 2019a). Continuing education is characterized by flexibility in time, place, content, learning technologies and many other features that contribute to the best training of students in modern conditions (Vaganova, 2019b). Modern advanced training courses should take these traits into account (Vaganova, 2019a). Therefore, today professional educational institutions are searching for the most appropriate technologies, methods and tools that meet the specifics of adult training (Pichugina \& Bondarchuk, 2019b). Project activity is currently one of the most effective ways to train employees of educational organizations. In this article, we consider the experience of organizing project activities in the system of professional development of teachers (Donetskova, 2019). In the process of project implementation, the project competence of students is formed, which is an integrative characteristic of the subject, which is expressed in the ability and readiness of a person to independently develop and implement a project (Bulayeva et al., 2019). This competence is of particular importance for modern students of advanced training 
courses. Professional activity of teachers is associated with the need to design the educational process, design the process of managing an educational institution and other functions related to project activities that affect the quality of the educational process.

The article deals with the implementation of project activities by students of the advanced training course "Management in education" (Chil Núnez et al, 2020). In the course of training, students solved educational and professional tasks in the conditions of project activity using the mastered algorithm of its organization.

\section{Theoretical framework}

Project activity is work on solving specific tasks, including agreed methods, methods of action (Vaganova et al., 2019c). It is of a creative research nature and involves individual and collective forms of organization (Aleksieienko-Lemovska, 2019). Scientists give dozens of definitions of this concept (Andriushchenko, 2018). Most often, project activity is understood as educational and cognitive activity (Osadchenko, 2019), which is based on motivation to achieve consciously set goals for creating a creative product through the consistent implementation of certain actions with the presentation of results at the final stage (Oros, 2019).

Implementation of project activities in the system of professional development opens up new opportunities for course participants (Pisarenko, 2019). One of the important advantages is the change in the position of students: from objects of an educational activity to full-fledged subjects, participants in the creative process (Myalkina, 2019). Students acquire the necessary practical skills to create project solutions and work in a team, organize, and distribute different types of project activities.

For effective management, the project must be clearly structured. To do this, the activity is divided into several stages. Different researchers take different approaches to their numbers and variations (Tsarapkina et al., 2019b). Most often, there are: diagnostic-determining the problem and its relevance (Tsarapkina et al., 2019a); predictive-drawing up a plan to achieve the planned results (Raven, 2017), calculating risks (Pliushch, 2018); organizational - creating conditions for ensuring effective work; practical - direct activity on product creation, process adjustment; generalizing - analysis of the results obtained.

The work of many scientists is devoted to the study of project activities. Among the functions of project management are: planning, control, analysis, and decision-making. The organization of the project activity of a teacher is revealed in the works of G. I. Kovaleva, V. M. Monakhov, T. K. Smykovskaya and others. V. G. Veselova, N. N. Golovin and other scientists consider project activity as a means of forming professional competence. Of particular interest to our research are works that reveal the impact of project activities on the cognitive activity of students (Filchenkova, 2019). This problem was developed by N. M. Konysheva, N. V. Matyash, E. S. Polat and others. A significant contribution to this topic was made by N. V. Seregina and N. N. Smagina and others. The works of N. G. Alekseev, G. A. Antyukhov, E. V. Boldyrev, L. V. Ivanova and others reflect the specifics of the organization of project training. To date, there is considerable theoretical and practical material on the topic of implementing project activities in professional education (Kobernyk, 2018). However, given the active development of this area and regular reform processes, there is a need for additional research in this area (Grigoriev et al., 2019).

\section{Methodology}

The research work carried out by us based on the Institute of directed education was attended by students of the advanced training course "Management in education". The study was carried out over three years (2017-2019). The total number of participants is 158 people. In 2017, 50 people took part, in $2018-53$, in $2019-55$. Students throughout the training period took part in various projects. Their training was a well-structured system of projects. Project tasks and methodological 
recommendations were developed for the students. The project task contains: analysis of the problem; goal setting; selection of means to achieve it, search and processing of information, evaluation of the results obtained (Arbeláez-Campillo, \& Rojas-Bahamon, 2020).

Methodological recommendations for the implementation of the project task include: General provisions, the algorithm of project activity, requirements for the design of the project, criteria for its evaluation. The research was carried out to check the formation of project competence of students.

Project activity occupies an important place in the system of professional development. Its implementation allows you to radically change the entire learning process, make it active, creative and independent. Training based on project activity allows you to form the subject position of the listener, the ability to plan, predict, organize, and design. In the course of training on the course "Management in education" they perform various projects: research, creative, game, information, practice-oriented. The entire educational process is a system of training projects that students must prepare. Themes of the projects on the course "Management in education" is associated with the development of models of management of educational institutions of secondary vocational education; a management of structural division of the institution of higher educational institutions, development of directions of development of the educational institution; control of the center of additional education. Students are trained in planning. In the course of the project, they form the skill of setting goals, describing the main steps to achieve it. Listeners engaged in the collection and processing of information. Use the ability to analyze, showing creativity and critical thinking (Pinkovetskaia et al, 2019). They work out the ability to make a written report (work plan, presentation of results, and so on). In this process, students actively develop their project competence.

At the final stage of training, the course participants complete the final project. For example, one of the projects is "Development of educational institution management" (College, higher education institution, center for additional education, etc.). Preparation for its protection is carried out throughout the entire period of training.

The purpose of the project implementation by students of the course: formation of the ability to define goals and tasks, forecast, design, effective independent individual activities and activities in a team.

When developing the project, students performed the following activities: identifying the problem that the project aims to solve; formulating current and final goals of the project and formulating ways to achieve them; collecting and analyzing information; developing documentation and identifying legislative acts based on which the project is implemented; monitoring the compliance of the proposed ideas with modern management requirements of the institution of additional education.

The students determined the main goal of their project. The goal of the project is to ensure the effectiveness of the health and Wellness educational center as an innovative multidisciplinary educational organization.

As the main normative documents for the development of the project, students are allocated: The Constitution of the Russian Federation, Federal law of the Russian Federation of December 29, 2012 N 273-FZ "on education in the Russian Federation".

The effectiveness of the project developed by students depended, among other things, on the construction of an algorithm for its implementation, determining the stages of its implementation. The participants identified three stages: stage 1 (preparatory), stage 2 (implementation), and stage 3 - final. Table 1 shows the content of each stage of the project activity. 
Table 1.

The content of the stages of project activities (as part of our study)

\begin{tabular}{|l|l|}
\hline Stage & Stage Content \\
\hline Stage 1 (preparatory) & $\begin{array}{l}\text { In turns the plan to determine the strategic directions of } \\
\text { development of existing institutions; conducting public } \\
\text { discussion and coordination of actions on the } \\
\text { implementation of the institution management development } \\
\text { project; implementation of long-term planning of } \\
\text { measures for the implementation of the project }\end{array}$ \\
\hline Stage 2 (implementation) & $\begin{array}{l}\text { In turns the implementation of the planned activities under } \\
\text { the project; development of criteria and performance } \\
\text { indicators for project implementation; monitoring of } \\
\text { the impact of project implementation }\end{array}$ \\
\hline Stage 3 (final) & There is an assessment of the results achieved. \\
\hline
\end{tabular}

To prepare the project, students were grouped into creative subgroups. A large part of the project preparation was carried out as part of independent work, so the electronic educational platform was actively used. It provides active interaction between students and students and teachers, prompt problem solving during online consultations.

Project implementation integrates students' implementation of problem-based, informational, interactive technologies, reflexive, presentative, research and search methods. In the course of the project, the students calculated the possible risks associated with the implementation of the project of managing a children's health and Wellness educational center.

Analyzing the nature of the project activity of students, we note that it develops the ability to define and formulate goals, independently organize, plan and control their activities and the activities of the working group to solve the project problem. Students acquire and improve subject and subject-methodical knowledge in the conditions of systematic development of project activities in conjunction with the development of personal and professional qualities, which will allow them to carry out professional activities.

At the final stage of the study, we determined the level of formation of project competence of students of the course "Management in education".

\section{Results and discussion}

We conducted a study among students of the advanced training course "Management in education", which was carried out for three years. We have determined the level of formation of project competence, which includes cognitive; communicative; creative; personal-motivational; activity-reflexive components. Project competence is expressed in the ability and readiness of a person to independently develop and implement a project. The indicators presented in table 2 were defined for each component of this competence.

Table 2.

Project Competency Framework (as part of our study) 


\begin{tabular}{|l|l|}
\hline Component & Indicators \\
\hline Cognitive & $\begin{array}{l}\text { The degree of development of cognitive processes; intellectual ability, the } \\
\text { ability to analyze specific situation that arose during the implementation of } \\
\text { the project }\end{array}$ \\
\hline Communicative & $\begin{array}{l}\text { Ability to work in a team; ability to avoid conflicts; work in the interests of } \\
\text { the team; focus on personality-oriented interaction in the team; ability to } \\
\text { objectively evaluate the interaction of project participants }\end{array}$ \\
\hline Creative & $\begin{array}{l}\text { Availability of researching creative activity; ability to find non-standard } \\
\text { solutions to emerging problems; flexibility, critical thinking }\end{array}$ \\
\hline $\begin{array}{l}\text { Personal- } \\
\text { motivational }\end{array}$ & $\begin{array}{l}\text { The presence of motivation to achieve success, manifestation of leadership } \\
\text { qualities; ability to take responsibility; emotional stability; focus on } \\
\text { successful results }\end{array}$ \\
\hline $\begin{array}{l}\text { Activity- } \\
\text { reflexive }\end{array}$ & $\begin{array}{l}\text { The presence of research abilities; ability to carry out current regulation of } \\
\text { project activities; ability to conduct reflection to adjust activities; mastery } \\
\text { of planning skills; strategy development skills }\end{array}$ \\
\hline
\end{tabular}

The definition of the level of development of project competence is shown in table 3. For each component, high, medium and low levels are allocated.

Table 3.

The results of statistical processing of data to identify the level of project competence (as part of our study)

\begin{tabular}{|l|c|c|}
\hline \multicolumn{1}{|c|}{$\begin{array}{c}\text { Competence Development } \\
\text { Levels }\end{array}$} & $\begin{array}{c}\text { Project Competency } \\
\text { Components }\end{array}$ & Results \\
\hline High & Cognitive & $66 \%$ \\
\hline Middle & & $54 \%$ \\
\hline Low & Communicative & $0 \%$ \\
\hline & & $90 \%$ \\
\hline High & & $10 \%$ \\
\hline Middle & Creative & $0 \%$ \\
\hline Low & & $70 \%$ \\
\hline & & $30 \%$ \\
\hline High & & $0 \%$ \\
\hline Middle & & $77 \%$ \\
\hline Low & Personal motivational & $23 \%$ \\
\hline & & $0 \%$ \\
\hline High & & $65 \%$ \\
\hline Middle & & $35 \%$ \\
\hline Low & & $0 \%$ \\
\hline & & \\
\hline High & & \\
\hline Middle & & \\
\hline Low & & \\
\hline
\end{tabular}

The results of statistical data processing showed that the majority of students of advanced training courses "Management in education" have a high level of development of project competence. Low levels were not detected in any of the groups that took part in the study. 


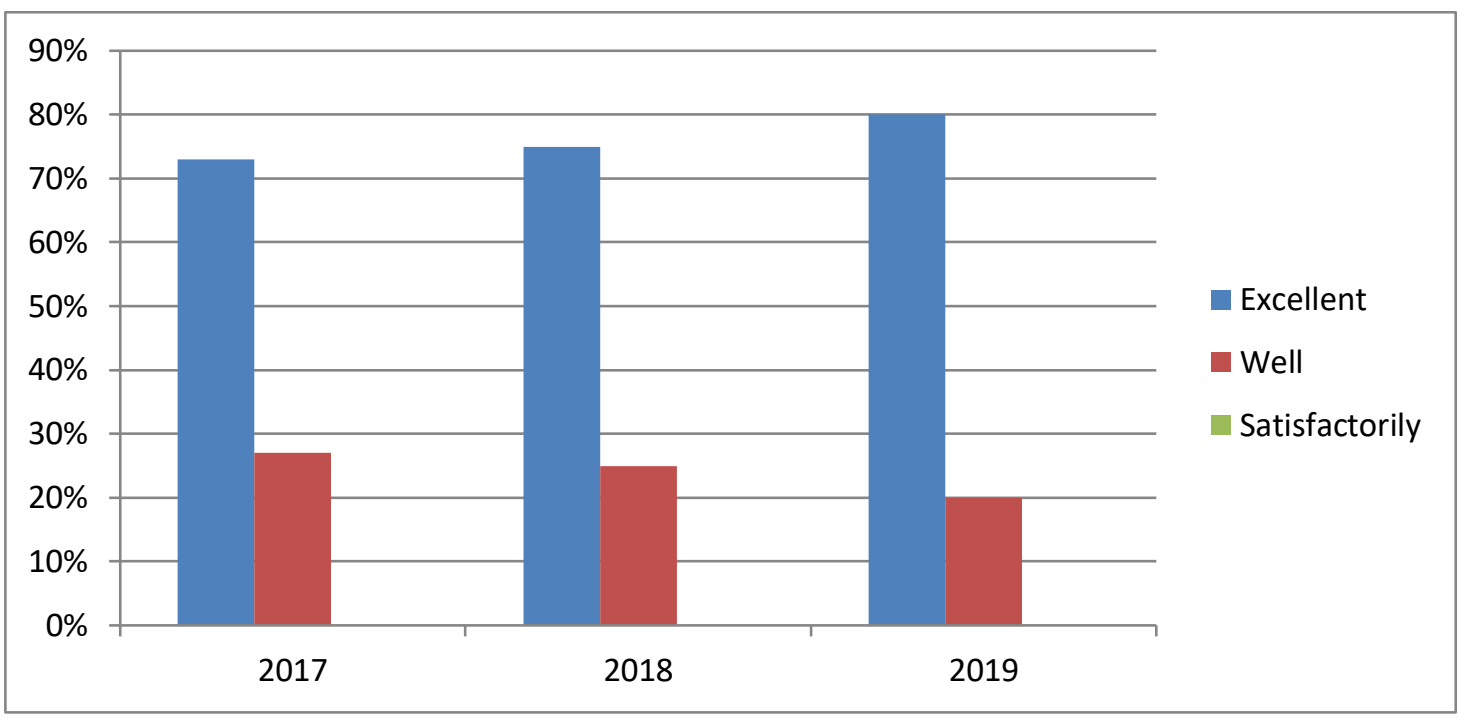

Figure 1. Evaluation of the implementation of the project system by students of the advanced training course "Management in education" (as part of our study)

The entire period of the study, starting from 2017, was marked by positive dynamics in the implementation of project work. Most students have high grades. The percentage of participants in the educational process with an excellent rating is growing every year. This gives us reason to believe that the implementation of the project system in the advanced training courses "Management in education" contributes to the effective formation of project competence and training of students in General.

\section{Conclusions}

We reviewed the experience of organizing project activities for students of the advanced training course "Management in education".

Project activity is an integrative type of activity that includes elements of cognitive valueoriented, communicative and creative activities. The project system implemented at the advanced training courses "Management in education" allowed students to develop project competence. This competence is significant for teachers and will allow them to carry out professional activities at a higher level. Project activity allows you to accumulate efforts to solve complex issues of activity, solve problems for the development of an educational organization, and form leading solutions in the context of global educational competition. The data obtained in the course of the study on the level of formation of this competence allow us to speak about the effectiveness of the implemented system of projects.

Conflict of interests: The authors declare that they have no conflicts of interest.

Authors' contribution: The authors have participated in the research process, in the writing of the work and in the analysis of the documents.

\section{Bibliographic references}

Aleksieienko-Lemovska, L.V. (2019). The activity approach as a basis for preschool teachers' methodological activities, Humanitarian Balkan Research, 3, 4(6), 10-14.

Andriushchenko, T. K. (2018). Personal aspects of pedagogue's innovative culture. Scientific Vector of the Balkans, 1, 13-16. 
Arbeláez-Campillo, D.F., \& Rojas-Bahamon, M.J (2020). "Pandemics in globalization times". Amazonia Investiga, $9(27), \quad 3-4$. https://amazoniainvestiga.info/index.php/amazonia/article/view/1189

Bakharev, N. P. (2019). Creativity - a prerequisite for the formation of professional competences in specialists of technical direction of training. Scientific Vector of the Balkans, 3, 4(6), $17-21$.

Bulayeva, M.N., Aleshugina, Ye.A. \& Maksimova, K.A. (2019). Modeling of the process of formation competence of teachers in university. Baltic Humanitarian Journal, 8, 3(28), 21-24.

Chil Núñez, I., Escalona Arranz, J., Molina Bertrán, S., Dutok Sánchez, C., Arias Ramos, D., Pérez Rondón, L., Ochoa Pacheco, A., \& Picanço Souto, R. (2020). Perfeccionamiento de la estrategia curricular de medio ambiente de la carrera de ciencias farmacéuticas de la Universidad de Oriente, Cuba. Revista Científica Del Amazonas, 3(5), 6-17. https://revistadelamazonas.info/index.php/amazonas/article/view/24

Donetskova, O.YU. (2019). Modernization of the modern education system in Russia. Baltic Humanitarian Journal, 8, 2(27), 37-39.

Filchenkova, I.F. (2019). Educational management of innovative activity of teachers as an object of pedagogical research. Vestnik of Minin University, 7(4), 3.

Grigoriev, S. G., Shabunina, V. A., Tsarapkina, Ju. M., \& Dunaeva, N. V. (2019). Electronic library system as a means of self-development of students of digital generation $\mathrm{Z}$ (on the example of studying the course "Basics of the counselor activity"). Scientific and technical libraries, 7, 78-99. 29.

Myalkina, E.V. (2019). Diagnostics of the education quality in the higher educational institution. Vestnik of Minin University, 7(3), 4.

Oros, I.I. (2018) The role of international connections in the development of the adult education system. Humanitarian Balkan Research, 1, 57-59.

Osadchenko, I.I. (2019). Key concepts of situational training technology in preparing future teachers. Scientific Vector of the Balkans, 1(3), 46-49.

Pichugina, G.A., \& Bondarchuk, A.I. (2019a). Structure of the training case in the organization of the educational process. Humanitarian Balkan Research, 2(4), 5-7.

Pichugina, G. A., \& Zhilyakova, D. A. (2019b) Structuring the organization of the process of creativity. Scientific Vector of the Balkans, 3, 3(5), 55-58.

Pinkovetskaia, I., Arbeláez, D.F., Rojas, M.J., Gromova, T., \& Nikitina, I. (2019). Female entrepreneurship development in the Russian Federation. Amazonia Investiga, 8(18), 111118. https://amazoniainvestiga.info/index.php/amazonia/article/view/287

Pisarenko, D. A. (2019). Evaluation of extracurricular activities of university students with a competency-based approach. Scientific Vector of the Balkans, 3, 3(5), 37-40.

Pliushch, V.M. (2018). Independent work of students as a factor of improving education quality. Balkan Scientific Review, 1, 69-71. 
Raven, J. (2017). Education and Sociocybernetics. Azimuth of Scientific Researches: Economics and Management, 6, 3(20), 289-297.

Tsarapkina, Ju.M., Petrova, M.M., Mironov, A.G., Morozova, I.M., \& Shustova, O.B. (2019a). Robotics as a basis for Informatization of education in children's health camp. Amazonia Investiga, $8(20)$.

115-123. https://www.amazoniainvestiga.info/index.php/amazonia/article/view/70

Tsarapkina, Ju. M., Dunaeva, N. V., \& Kireicheva, A. M. (2019b). Application of BYOD technology in education on the example of Lecture Racing mobile application, Informatics and Education, 9(308), 56-64.

Vaganova, O.I., Ilyashenko, L.I., Smirnova, Zh.V., Bystrova, N.V., \& Kaznacheeva, S.N. (2019a) Students' creative abilities development in higher educational institution. Amazonia Investiga, $8(22)$, $701-710$ https://www.amazoniainvestiga.info/index.php/amazonia/article/view/822

Vaganova, O.I., Rudenko, I.V., Markova, S.M., Smirnova, Zh.V., \& Kutepov, M.M. (2019b). The use of educational video materials in educational process of a higher educational institution. Amazonia Investiga, 8(22), 216-222. https://www.amazoniainvestiga.info/index.php/amazonia/article/view/308

Vaganova, O.I., Livshits, Yu.A., Aleshugina, E.A., Smirnova Zh.V., \& Kutepova L.I. (2019c) Experience in developing electronic glossary in a higher education institution. Amazonia Investiga, $8(22)$ 247-253. https://www.amazoniainvestiga.info/index.php/amazonia/article/view/421 